\title{
Accounting Factors, Non-Accounting Factors, and Net Initial Return
}

\author{
Dhian Nurul Hidayati \\ Telkom University \\ Dedik Nur Triyanto \\ Telkom University
}

\begin{abstract}
The research aims to analyze accounting and non-accounting factors that influence the level of Net Initial Return (NIR). Accounting factors contain Return on Asset (ROA), Debt to Equity Ratio (DER), and Firm Size. Non-accounting factors contain Firm Age, Offering, and Underwriter Reputation. Furthermore, the research has the purpose of finding any simultaneous and partial influence. The research is using a quantitative method. The population is 149 companies that have made any Initial Public Offering (IPO) on the Indonesia Stock Exchange from 2014-2018. The sample-based on purposive sampling results which are 95 companies. Multiple linear regression analysis was applied in this research using EViews 10. Simultaneously, the result indicates that ROA, DER, Firm Size, Firm Age, Offering, Underwriter Reputation have a significant influence on NIR. However, partially, the results showed that only ROA and Underwriter Reputation have a negative and significant effect on NIR. Meanwhile, DER, Firm Size, Firm Age, and Offering do not have a substantial effect on NIR.
\end{abstract}

Keywords: Accounting Factors; Non-accounting Factors; Initial Public Offering; Net Initial Return

\section{Introduction}

Capital markets are becoming something essential and very valuable in the world. The globalization process from the financial side made the capital market the spearhead that globalization touched, imagine the benefit that can be taken from the freedom of moving capital as an effect of globalization that occurred (Widoatmodjo, 2015:2). Dynamically capital market activities in a country will draw how good the business climate in that country, it can be said that a capital market is a place for a businessman when looking for additional funding while another resource is deemed not enough (Fahmi, 2015:16).

Many companies decided to make Initial Public Offering (IPO) or go public to gain financial support on the primary market caused a new problem, which is the competition between companies to get an investor. Go public activities are colored by a general phenomenon that usually occurred in the capital market, which is the emergence of a

definite difference between closing stock price in secondary market and stock market price on its first offer when making Initial Public Offering (IPO), which commonly called underpricing (Puspita, 2011). Often happens the information asymmetric during the Initial Public Offering (IPO), where there was a difference in knowledge of the information on the company. It occurred when one side knew more (usually the developer), and another side left vulnerable, which is an investor.

One of the effects of information asymmetric which is the difference between the stock price that is traded during Initial Public Offering and the closing stock market on the first day in the secondary market. If the stock price during Initial Public Offering is higher than the closing stock price, it can be called overpricing. Meanwhile, if the stock price during Initial Public Offering is lower than the closing stock price, it can be called 
underpricing (Hasanah \& Akbar, 2014). To minimize asymmetric information, companies that make Initial Public Offering must issue a prospectus (Setyantoto, 2017). The prospectus is a statement that printed or information such as an official document that is used to bid effect with intent to influence other parties to buy or sell the company's effect who were making Initial Public Offering. On the other side, for issuers, prospectus had a meaning like a commercial that useful to tempts the investor to buy the effects that being sold (Widoatmodjo, 2015:83).

Based on data from BEI Fact Book during the last five years, companies that just done Initial Public Offering or companies that go public experienced underpricing more than overpricing; as a result, their net initial return is high, this underpricing phenomenon is becoming a motivation for the investor to invest when companies go public (Prawesti \& Indrasari, 2016). The investor did it because investor hopes to get higher Net Initial Return, Net Initial Return is a benefit investor can get because of a price difference between the closing price and offering price. The opinion of Wiguna \& Yadnyana (2015) state that Net Initial Return is an early profit that investor gets.

Offering price during Initial Public Offering that increase significantly when being sold in the secondary market, causing the funding that company gets when going public became less optimum because here investor gets the profit and company get lost. On the other hand, if the offering price is higher than selling price in the secondary market, an investor who will be lost Net Initial Return from the sales of its shares. That is the cause of the Net Initial Return phenomenon or can be called underpricing events. Two factors can cause underpricing, which are accounting and nonaccounting factors.

Accounting Factors contains Return on Asset, Debt to Equity Ratio, and Firm Size. Meanwhile, non-accounting factors contain Firm age, Offering, and Underwriter Reputation. What variables have been widely taken in some research by previous researchers, but still, show variations of research results or inconsistencies occur. The purpose of the study is to reveal the influence of accounting and nonaccounting factors on the level of Net Initial Return (NIR).

\section{Literature Review and Hypothesis Development}

\section{Signaling Theory}

The Signalling Theory explains why the company has the urge to provide financial reporting information to external parties. The urge aims to increase the value of the company and demonstrate that the company has more value or competitive advantage than other companies. The Signalling Theory suggests about how a company should give signals to users of financial statements. It is explained that information about the company is a signal for investors in investing decisions (Purwanto, 2012).

The Signalling Theory assumes that publishers have the comprehensive information about the company's value, as investors are uninformed entities that do not know the company's information, which then assesses the company as a function of different signaling mechanisms. The Signalling Theory is a possible theory to explain the phenomenon of underpricing in the comprehensive Initial Public Offering (IPO) (Kurniawan \& Haryanto, 2014).

\section{Net Initial Return (NIR)}

Net Initial Return is the initial profit obtained by the shareholders because there is a difference in the stock price purchased in the first market (IPO) with the closing price of the corresponding stock on day one in the secondary market (Wiguna \& Yadnyana, 2015). Underpricing is the cause of Net Initial Return. The initial stock price that underpricing will give the Net Initial Return with a positive average for investors after the shares are traded on the Exchange (Pahlevi, 2014).

\section{Return on Asset (ROA)}

Return on Asset (ROA) is a crucial profitability ratio used to measure the company's ability with an implanted investment or an asset it possesses for profit (Syukur, Fathoni, \& Gagah, 2016). The level of achievement of a company is usually measured by profit. The profitability ratio plays a vital role in achievement scoring and is often used as a basis in investment decisions. 
Companies with a high Return on Asset (ROA) demonstrate the company's ability to generate profit in the future, thereby reducing investor uncertainty (Pahlevi, 2014). High ROA of companies will be attracted by many investors, causing investors willing to buy their maiden shares at a higher price. If the bid price is high, then it can reduce the underpricing level. The research by Setyowati \& Suciningtyas (2018) and $\mathrm{Xu}$, Gong, \& Gong (2017) stated that ROA was significantly influential in the negative direction against NIR. Contrary to the research conducted by Rastiti \& Stephanus (2015) and Syukur et al. (2016) stating that ROA had no significant influence on NIR.

\section{Debt to Equity Ratio (DER)}

Debt to Equity Ratio (DER) describing the company's ability to pay off liabilities with Equity (Rastiti \& Stephanus, 2015). Debt to Equity Ratio (DER), or debt to equity ratio, explains the comparisons between debts and equity in the company's funding and demonstrates the ability of its capital to fulfill its obligations or how much the company Financed by the creditors in comparison with the equity (Sujarweni, 2017). The higher the ratio of solvency (leverage ratio), the worse the company's ability to pay for its long-term obligations; the maximum value is $200 \%$ (Wardiyah, 2017:107).

The small value of Debt to Equity Ratio (DER) signifies that the company does not use debt as a significant source of expansion, and it is a good thing. The small value of Debt to Equity Ratio (DER) will also make the company stand in case of bad things in the business, and that could have a financial impact. In case of a crisis, a company that has a small debt and a capital that will be able to survive in comparison with the debt above its capital (Herlambang, 2017).

The company with the high DER has the possibility of experiencing a high underpricing as well. The research by Pahlevi (2014) and Wiguna \& Yadnyana (2015) stated that DER significantly influenced the positive direction of NIR. Contrary to research by Syukur et al. (2016) and Setyowati \& Suciningtyas (2018), indicating that DER significantly affects the negative direction against NIR.

\section{Firm Size}

The size of the company can reflect the wealth owned by a company in the potential of generating cash flows, as well as able to present information widely that can reduce the risk of uncertainty of a company so that it can increase Investor confidence. Total assets in each company have a different amount to measure the size of the company can use natural logarithm by transforming the total assets (Sembiring, Rahmawati, \& Kusumawati, 2018). According to Wiguna \& Yadnyana ( 2015), the variable firm size is measured using the natural logarithm of the total company assets in the last period before the company performs the IPO.

Companies with a large scale tend to be known by the public because of the ease in access to information so that investors are easy to measure the prospects of the company in the future (Sembiring et al., 2018). If investor interest is high, then the automatic offer price will be high so that it will reduce the underpricing level. Research conducted by Kurniawan \& Haryanto (2014), Mayes \& Alqahtani, (2015), and Xu et al. (2017) showed that Firm Size was significantly influential in the negative direction against NIR. Contrary to the research conducted by Sembiring et al. (2018) and Badru \& Ahmad-Zaluki (2018), which states that Firm Size significantly affects the positive direction of NIR.

\section{Firm Age}

The company's age shows the company's lifespan from standing up to an IPO where the more extended the company stands then the more historical information can reduce the risk of uncertainty (Rastiti \& Stephanus, 2015). The company's age is considered by investors to invest in its capital. The company's longstanding age suggests that the company already has the experience and the ability to survive the business competition. The information about the date of incorporation of the company can be known to the company's prospectus (Wiguna \& Yadnyana, 2015).

Investors are more confident to invest their funds in the IPO company. The high interest of investors makes the bidding prices expensive so that it can reduce underpricing. Research by Kurniawan \& Haryanto (2014) and Mayes \& Alqahtani (2015) showed the Firm 
Age significantly with a negative direction against NIR. However, research by Rastiti \& Stephanus (2015), Wasiuzzaman, Yong, Sundarasen, \& Othman (2018), as well as Sundarasen (2019), stated that the firm age has no significant effect on NIR.

\section{Offering}

Offering or the percentage of the share offering to the public is a comparison between the number of shares sold to the public at the IPO with the outstanding share of shares (Syukur et al., 2016). The offering is the number of shares offered to the public, indicating the public will own how much part of the paid-up capital. The higher the number of stocks offered will have the potential to store trade the stock On the Exchange (Darmadji \& M.Fakhruddin, 2011:72). High-value companies will tend to withhold ownership of their shares.

The percentage of shares offered can be used as a proxy for the uncertainty factor that the investor will receive and show the flow of information from the issuer's share to the prospective investor. The smaller percentage of shares offered will minimize uncertainty in the future (Hartanto \& Arfianto, 2014). In other words, the higher the proportion of stocks offered to new shareholders, the higher the degree of insecurities so that the price set at the IPO is low. The low offer price has a high chance of underpricing. It causes the Net Initial Return to be accepted by the investor. The higher the stock offering rate than the higher the underpricing rate. The research by Khin, Wahh, \& Mohammad, (2016) and Prawesti \& Indrasari (2016) showed a significant influence on the positive direction against NIR. However, the research was done by Rastiti \& Stephanus (2015), and Syukur et al. (2016) state that Offering does not affect NIR.

\section{Underwriter Reputation}

The underwriter is the guarantor of emission for each company that will issue its shares in the capital market. In other words, that the reputation of an underwriter is essential to be stated that whether the company is worthy of going public or not (Fahmi \& Hadi, 2009:49). The underwriter works in the guarantee of the public offering of the shares or bonds for the first time at the time of going public. This securities company will market and guarantee the sold or whether the securities are issued or offered by a company. In conducting the emission guarantee, an effect, usually, underwriters form a group consisting of lead underwriters and underwriter members (guarantors). An Underwriter effect on the company is conducted by signing an emission guarantee contract between lead underwriters and issuers.

The reputation of a good underwriter can lower the risk level and uncertainty of the company so that investors have a high interest in buying shares of such IPO companies. The more interest the investor will be, the higher the price of the offer can result in a decrease in underpricing. Research by Rastiti \& Stephanus (2015), Sundarasen (2019), as well as Budianto, Suhadak, Rahayu, \& Dzulkirom (2019) showed that the reputation Underwriter had a significant negative influence on NIR. It is different from research by $\mathrm{Xu}$ et al. (2017) and Badru \& Ahmad-Zaluki (2018), stating that the Reputation Underwriter does not influence NIR.

\section{Return on Assets (ROA) and Net Initial Return}

Return on Assets (ROA) to illustrate the extent to which the company's assets can generate profit for the company. ROA's Net Initial Return explains if a company with a high profit and improved provides an overview of or information that the company has an excellent company performance (Pahlevi, 2014). The company with a high ROA demonstrated the company's ability to generate profit in the future, and it will attract investors because it is considered a profitable company. It can reduce the uncertainty of investors in buying shares at the time of the IPO (Setyowati \& Suciningtyas, 2018).

High ROA companies will be attracted by many investors (Yovita \& Amrania, 2018), causing investors willing to buy their maiden shares at a higher price. If the offer price is high, then it can reduce the underpricing level. The research by Setyowati \& Suciningtyas (2018) and (Xu et al., 2017) stated that ROA was significantly influential in the negative with NIR.

Hypothesis 1: Return on Assets (ROA) has a significant negative direction towards Net Initial Return. 


\section{Debt to Equity Ratio (DER) and Net Initial Return}

Debt to Equity Ratio (DER) demonstrates the ability of the company to pay its debts with its capital (Syukur et al., 2016). The DER theoretically shows the company's risk and uncertainty conditions. The height of the company's DER ratio will show the higher the financial risk or failure risk of the company to restore its loan so that it can affect the stock price-fixing at the time of the IPO (Pahlevi, 2014). The high level of risk and uncertainty causes investors to think twice about buying shares of the IPO company. If investor interest is low, then the bid price will also low. Therefore, the authors argue that the company with the high DER has the possibility of experiencing a high underpricing as well. The research by Pahlevi (2014) and Wiguna \& Yadnyana (2015) stated that DER significantly influenced the positive direction of NIR.

Hypothesis 2: Debt to Equity Ratio (DER) has a significant positive direction towards Net Initial Return.

\section{Firm Size and Net Initial Return}

Firm Size reflects the company's ability to generate cash flows and can present information broadly to reduce the risk of uncertainty so that it will increase the trust of potential investors. Companies with a large scale tend to be known by the public because of the ease in access to information so that investors are easy to measure the prospects of the company in the future (Sembiring et al., 2018). If investor interest is high, then the automatic bid price will be high, so it will reduce the underpricing level. Research conducted by Kurniawan \& Haryanto (2014), Mayes \& Alqahtani (2015), and Xu et al. (2017) showed that Firm Size was significantly influential in the negative direction against NIR.

\section{Hypothesis 3: Firm Size has a significant} negative direction towards Net Initial Return.

\section{Firm Age and Net Initial Return}

Firm Age is information about the company's ability to survive. Companies that have long- established can be used as an indication that the company has much experience and exceptional ability to survive. Firm Age can be used as a reference to reduce information asymmetry and reduce the risk of future uncertainty so that it can increase investor confidence (Pahlevi, 2014). This trust can make investors confident to invest their funds in the IPO company. More interest in investors makes bidding prices expensive so that it can reduce underpricing. Research by Kurniawan \& Haryanto (2014) and Mayes \& Alqahtani (2015) showed the Firm Age significantly with a negative direction against NIR.

Hypothesis 4: Firm Age has a significant negative direction towards Net Initial Return.

\section{Offering and Net Initial Return}

Offering or percentage of shares offered to the public shows the private information owned by a company. The larger the percentage of shares that are offered to the public the higher the level of uncertainty in the future. It is because the old shareholders will have smaller private information, so the level of uncertainty borne by the investor is greater. To make investment decisions, prospective investors need much information to consider buying or not the shares that the company offers the issuer (Pahlevi, 2014).

Another opinion says the higher the number of shares ownership held by the company will result in a smaller percentage of the stock offerings offered to the public. At the time, the number of shares offered to the public is slight, resulting in a price set in the prime market that will be increasingly expensive. When the initial stock price is high, the investor will reconsider his decision to buy the stocks that the company offers. Investors are worried about the price of stocks too high at the time of bidding because it will impact the return gained in the future.

The high price of a stock quote is indicative of a decrease in the closing price due to low investor interest. It causes the Net Initial Return to be accepted by the investor. The higher the stock offering rate, then the higher the underpricing rate. The research of Khin et al. (2016) and Prawesti \& Indrasari (2016) showed a significant influence on the positive direction against NIR. 
Hypothesis 5: Offering has a significant positive direction towards Net Initial Return.

\section{Underwriter Reputation and Net Initial Return}

Effect guarantor or commonly called underwriter is a securities company that contracts with issuers to carry out the public offering and/or without the obligation to purchase the remainder of the unsold securities (full commitment and non-full commitment). The reputation of a good underwriter can lower the risk level and uncertainty of the company so that investors have a high interest in buying shares of such IPO companies. The more interest the investor will be, the higher the price of the offer can result in a decrease in underpricing. The research by Rastiti \& Stephanus (2015), Sundarasen (2019), as well as Budianto et al. (2019), showed that the reputation Underwriter had a significant negative influence on NIR.

Hypothesis 6: Underwriter Reputation has a significant negative direction towards Net Initial Return.

\section{Methods}

Sampling

The population used in this research is a company that performs an Initial Public Offering (IPO) on the Indonesia Stock Exchange during the 2014-2018 period for 149 companies. The sampling techniques used are non-probability sampling or purposive sampling with sample determination criteria as in the table below:

Table 1. Purposive Sampling

\begin{tabular}{clc}
\hline No & \multicolumn{1}{c}{ Sample Criteria } & Total \\
\hline 1. & $\begin{array}{l}\text { Companies that perform Initial Public Offering (IPO) and listings in IDX } \\
\text { during the 2014-2018 period. }\end{array}$ & 149 \\
2. & $\begin{array}{l}\text { Companies that do not have complete prospectus data during the 2014-2018 } \\
\text { period. }\end{array}$ & (42) \\
3. & $\begin{array}{l}\text { Companies that not having underpricing in the first offer or Initial Public } \\
\text { Offering (IPO) during the 2014-2018 period. }\end{array}$ & (12)
\end{tabular}

Total Research Samples 95

Source: Data that has been processed (2019)

\section{Measures}

The type of research used in this study is quantitative research. The following is the calculation of accounting variables consisting of Return on Assets (ROA), Debt to Equity Ratio (DER), and Firm Size used as well as the calculation of non-accounting variables consisting of Firm Age, Offering, and Underwriter Reputation.

Table 2. Variables Operationalization

\begin{tabular}{llc}
\hline Variable & Operationalization & Scale \\
\hline Net Initial Return (NIR) & $\frac{\text { Closing Price - Offering Price }}{\text { Offering Price }} \times 100 \%$ & Ratio \\
Return on Assets (ROA) & $\frac{\text { EBIT }}{\text { Total Assets }} \times 100 \%$ & Ratio \\
$\begin{array}{l}\text { Debt to Equity Ratio } \\
\text { (DER) }\end{array}$ & $\frac{\text { Total Liabilities }}{\text { Total Equity }} \times 100 \%$ & Ratio \\
Firm Size & Ln. Total Assets & Ratio \\
\hline
\end{tabular}




\begin{tabular}{lcc}
\hline Firm Age & Year of IPO - Year of Company Standing & Ratio \\
Offering & $\frac{\text { Number of Shares Offered to the Public }}{\text { Number of Shares Outstanding }} \times 100 \%$ & Ratio
\end{tabular}

Underwriter Reputation

\begin{abstract}
The reputation of the underwriter is expressed as a dummy variable: 1 ) If a company has multiple underwriters of The Securities and none of which belong to The Big Ten group, then it is categorized as non-prestigious with a value (0), 2) If a company has several underwriters and is at least one of the securities that belong to The Big Ten, then categorized prestigious with a value (l)
\end{abstract}

Nominal

regression tests. In this test, it is necessary to test classic assumptions to provide representative results. Before entering the test/analysis data and hypothesis testing, it will first be described as the condition of the data used in the study.

\section{Descriptive Statistics}

The descriptive statistical analysis was carried out using preliminary data of 95 company samples after outlier data was obtained as much as 81 of the company's sample after issuing 14 outlier company data.

Table 3. Descriptive Analysis

\section{NIR ROA DER Firm Size Firm Age Offering Underwriter}

\begin{tabular}{lccccccc}
\hline Observations & 81 & 81 & 81 & 81 & 81 & 81 & 81 \\
Mean & 0.456318 & 0.073374 & 2.720027 & 27.05591 & 16.34568 & 0.227287 & 0.345679 \\
Maximum & 0.700000 & 0.283769 & 38.50427 & 29.84549 & 45.00000 & 0.481481 & 1.000000 \\
Minimum & 0.003472 & -0.058995 & 0.030689 & 22.97348 & 2.000000 & 0.004743 & 0.000000 \\
Std. Dev. & 0.248667 & 0.075358 & 5.677789 & 1.359276 & 11.00586 & 0.112614 & 0.478552 \\
\hline
\end{tabular}

Source: Output EViews 10

Based on information from Table 3 above, each of the minimum values, maximum value, average (mean), and standard deviation with the total amount of 81 data. It is known that the dependent variable of this study is NIR. The mean value is 0.456318 which indicates there are 58 companies whose NIR values are above average and 23 companies whose values are below average. It shows that 58 companies are experiencing high underpricing.

The mean value of ROA variable is 0.073374 . There are 38 companies whose ROA values are above average and 43 companies whose values are below average. It indicates that more companies have ROA below average. The mean value of DER variable is 2.720027 which indicates there are 22 companies whose DER values above average and 59 companies whose values are below average. Shows that more companies have the DER below average. The mean value of the Firm Size variable is 27.05591, which indicates there are 41 companies whose Firm Size value is above average and 40 companies whose value is below average. It shows that more companies have a Firm Size above average. 
The mean value of the Firm Age variable is 16.34568 which indicates there are 34 companies whose Firm Size values are above average and 47 companies whose values are below average. It shows that more companies have a Firm Size below average. The mean value of the Offering variable is 0.227287 which indicates there are 39 companies whose Offering value is above average and 42 companies whose values are below average. It shows that more companies have an Offering below the average. The value of the Underwriter Reputation company, which included in the Big Ten, is 28 companies and 53 other companies not classified into the Big Ten.

\section{Analysis of Multiple Linear Regression Models}

The results of linear regression analysis using EViews software version 10 are presented in Table 6.

Table 6. Multiple Linear Regression

\begin{tabular}{crrrr}
\hline \hline Variable & Coefficient & Std. Error & t-Statistic & Prob. \\
ROA & 1.539229 & 0.535203 & 2.875974 & 0.0053 \\
DER & -1.228269 & 0.326427 & -3.762769 & 0.0003 \\
FIRM_SIZE & -0.000686 & 0.004231 & -0.162242 & 0.8716 \\
FIRM_AGE & -0.033800 & 0.019296 & -1.751607 & 0.0840 \\
OFFERING & -0.003463 & 0.002235 & -1.549347 & 0.1256 \\
UNDERWRITER & 0.094729 & 0.226584 & 0.418073 & 0.6771 \\
R-Squared & -0.119667 & 0.052943 & -2.260286 & 0.0267 \\
\hline Adjusted R-squared & 0.339334 & Mean dependent var & 0.456318 \\
S.E. of regression & 0.285766 & S.D. dependent var & 0.248667 \\
Sum Squared resid & 0.210154 & Akaike info criterion & -0.199498 \\
Log likelihood & 3.268185 & Schwarz criterion & 0.007430 \\
F-statistic & 15.07966 & Hannan-Quinn criter. & -0.116476 \\
Prob(F-statistic) & 6.334696 & Durbin-Watson stat & 1.746930 \\
\hline \hline
\end{tabular}

Source: Output EViews 10

\section{Coefficient of Determination $\left(R^{2}\right)$}

Based on Table 6, the results of the coefficient of Determination $\left(\mathrm{R}^{2}\right)$ Test are used to measure how far the ability of the independent variables used in models can explain the dependent variables. From Table 6 generated R-Square Adjusted value of 0.285766 or $28.57 \%$ which means that the independent variables of ROA, DER, Firm Size, Firm Age, Offering, and Underwriter Reputation can explain other factors outside the research variables influence the dependent variables that are Net Initial Return of $28.57 \%$ and the remaining $71.43 \%$.

\section{F Test}

Based on Table 6, the F test was used to test the significance of the influence between ROA, DER, Firm Size, Firm Age, Offering, and Underwriter's Reputation for Net Initial Return on IPO companies on the Indonesia Stock Exchange simultaneously. In Table 6 It is known that Prob(F-Statistic) is worth 0.000021 $<(\alpha)=5 \%(0.05)$ then $\mathrm{H}_{0,1}$ rejected or $\mathrm{H}_{\mathrm{a}, 1}$ accepted, this indicates that simultaneously ROA, DER, Firm Size, Firm Age, Offering, Underwriter Reputation can explain the effect on Net Initial Return or it can, that all independent variables are simultaneously influential to NIR.

\section{T-Test}

Based on the information presented in Table 6 , the partial analysis indicated that Return on Assets (ROA) and Underwriter Reputation have a negative and significant effect on Net Initial Return. It was shown with the value ofstatistical probability that is smaller than the value of $(\alpha)=5 \%$. The other variables are DER, Firm Size, Firm Age, and Offering does not have a significant effect on Net Initial Return because t-statistical probability value is higher than $(\alpha)=5 \%$. Based on the results of the model analysis of multiple linear regression in the study, it resulted in an equation as seen below: 
$N I R=1.539229-1.228269$ ROA -0.000686

DER - 0.033800 FIRM_SIZE - 0.003463

FIRM_AGE + 0.094729 OFFERING -

0.119667 UNDERWRI $+\varepsilon$

\section{Discussion}

ROA has a significant effect on a negative direction on NIR. With a negative influence, it means that the higher a company's ROA can reduce the level of uncertainty in which it can increase investor interest in embedding its capital because the company is deemed able to Generate profit by utilizing the assets of the company (Setyowati \& Suciningtyas, 2018). If the interest of the investor is high, it will result in the high price of the initial stock quote when the company IPO so that it will result in a decline against NIR. The results of this study supported the research conducted by Setyowati \& Suciningtyas (2018) and Xu et al. (2017).

DER does not affect NIR. The larger the DER then, the higher the tendency of NIR does happen. However, it does not mean that a company cannot do IPO when it has significant debt because one of the company's motivations in go public is raising public funds to pay off the company's debts. It can be concluded that large or small DER values do not influence NIR. The results of this study supported the research done by Rastiti \& Stephanus (2015).

Firm Size does not affect NIR because the company is conducting an IPO does not need to have a large company asset. This IPO process assists in raising funds or capital for the expansion of the company, so it can add to the company's assets both current assets and fixed assets. Based on this, it can be concluded that the large or small value of the Firm Size has no influence on NIR. The results of this study supported the research done by Rastiti \& Stephanus (2015) and Wasiuzzaman et al. (2018).

Firm Age does not affect NIR because it cannot be considered as consideration for investors to make an investment decision. From several companies that have been operating long enough have a high underpricing level at the time of IPO. Although the company has had quite a long operation, the reason the company performs an IPO is also a consideration for investors who will be offered stocks. Because corporate credibility cannot be measured from how long the company stands. The longestablished company has not yet ensured that the company has also been running well (Wiguna \& Yadnyana, 2015). Based on this, it can be concluded that large or small Firm Age values do not influence Net Initial Return. The results of this study supported the research done by Rastiti \& Stephanus (2015), Wasiuzzaman et al. (2018), as well as Sundarasen (2019).

The offering does not affect NIR because the large share of the stocks offered to the public has not been able to explain the prospects of a company in the future. Although the proportion of the stocks offered is high, it does not mean that the private information of the company is not present and has not been able to determine the value of the return uncertainty given (Pahlevi, 2014). Based on this, it can be concluded that a large or small Offering does not influence NIR. The results of this study supported the research done by Rastiti \& Stephanus (2015) and Syukur et al. ( 2016).

Underwriter's reputation has a significant effect on the negative direction of NIR. The research showed that reputation underwriters have been able to reduce NIR levels. It is in accordance with the theory that the higher the Underwriter Reputation will be, the lower the level of NIR, the uncertainty in determining the initial share price will be less because the underwriter has a good reputation. The higher the reputation that underwriters have will affect underpricing. The results of this study supported the research done by Rastiti \& Stephanus (2015), Sundarasen (2019), and Budianto et al. (2019).

\section{Conclusion}

Based on the analysis and discussion in the previous section, the conclusions are as follows; Simultaneously, accounting and nonaccounting variables influence Net Initial Return. However, partially not all have an influence, accounting variables that affect the Net Initial Return in the negative direction of variable ROA, while for non-accounting variables that affect the Net Initial Return in the direction negative is the Underwriter Reputation variable. It indicates the importance of the role of the ROA variable and Underwriter's reputation in determining the initial stock price to reduce underpricing. 
The limitation of this research is the uncompleted data prospectus company that performs an Initial Public Offering (IPO) in the Indonesia Stock Exchange, thereby affecting the number of samples in the study. Besides, some data must be issued due to outliers.

Hopefully, this research can be used as a material or reference in the development of science accounting, especially in areas related to stock or Net Initial Return. It is hoped that further researchers have broader implications for research on similar topics as well as can add, subtract, or replace research variables that are not analyzed in this study so that they can explain about underpricing more extensively.

For the prospective investors who will invest in the company, go public should consider the information contained in the prospectus to get a high NIR. Also, investors can consider the decisions taken if they want to invest their shares in a public company that has a high ROA or who has a reputation for good underwriters if the objective of investors wants the maximum profit from the stock price difference at the time of closing in the secondary market.

For all companies who will or are conducting the initial public offering process or an IPO may consider increasing the company's ROA value or choosing a company with a good reputation. It has to be done so that the company can determine the bid price appropriately. It is expected that such actions may lower the level of NIR that will occur at the time of closure on the first day of the secondary market. Thus, the general bidding process can generate maximum capital replenishment for the company.

\section{References}

Badru, B. O., \& Ahmad-Zaluki, N. A. (2018). Asian Review of Accounting Article information: Explaining IPO initial returns in Malaysia: ex-ante uncertainty versus signaling. Asian Review of Accounting, 26(1), 84-106. https://doi.org/10.1108/ARA-11-2016$\underline{0133}$

Budianto, K., Suhadak, Rahayu, S. M., \& Dzulkirom, A. R. M. (2019). Effect of Accounting Information and NonAccounting Information on UnderPricing Ipo and Firm Value: a Study of Companies Listed on the Indonesia Stock
Exchange During Period of 2008-2014. Russian Journal of Agricultural and Socio-Economic Sciences, 89(5), 69-75. https://doi.org/10.18551/rjoas.2019-05.09

Darmadji, T., \& M.Fakhruddin, H. (2011). Pasar Modal di Indonesia. Jakarta: Salemba Empat.

Fahmi, I. (2015). Pengantar Teori Portofolio dan Analisis Investasi (S. Idris, Ed.). Jakarta: Alfabeta CV.

Fahmi, I., \& Hadi, Y. L. (2009). Teori Portofolio dan Analisis Investasi : Teori dan Soal Jawab. Bandung: Alfabeta CV.

Hartanto, L., \& Arfianto, E. D. (2014). Analisis Faktor-Faktor yang Mempengaruhi Kegagalan IPO. Diponegoro Journal of Management, No.4 Volume 3 ISSN: 2337-3792, 3(4).

Hasanah, \& Akbar, D. A. (2014). Analisis Faktor-Faktor Yang Mempengaruhi Tingkat Underpricing Saham di Bursa Efek Indonesia. Jurnal Manajemen.

Herlambang, G. (2017). Stock dan Saham. Retrieved October 5, 2019, from http://www.stockdansaham.com

Khin, E. W. S., Wahh, W. B., \& Mohammad, N. (2016). An Analysis of Initial Public Offering (IPO) Underpricing on Smes Firms Performances. International Journal of Research Science \& Management, 3(6), 21-32. Retrieved from http://www.ijrsm.com

Kurniawan, W. W., \& Haryanto. (2014). Pengaruh Pengungkapan Intellectual Capital dalam Prospektus terhadap Underpricing Saham. Diponegoro Journal of Accounting, 3(2), 1-14. Retrieved from http://ejournals1.undip.ac.id/index.php/accounting

Mayes, D., \& Alqahtani, F. (2015). Underpricing of IPOs in Saudi Arabia and Sharia Compliance. Journal of Islamic Accounting and Business Research, 6(2), 189-207. https://doi.org/10.1108/JIABR12-2013-0042

Pahlevi, R. W. (2014). Analisis Faktor-Faktor yang Mempengaruhi Underpricing Saham Pada Penawaran Saham Perdana di Bursa Efek Indonesia. Jurnal Siasat Bisnis, 18(2), 219-232. https://doi.org/10.20885/jsb.vol18.iss2.ar $\underline{\mathrm{t} 8}$

Prawesti, L., \& Indrasari, A. (2016). Analisis Peranan Informasi Akuntansi Dan Non Akuntansi Terhadap Initial Return Saham. 
Jurnal Benefita, 1(1). https://doi.org/10.22216/jbe.v1i1.932

Purwanto. (2012). Pengaruh Manajemen Laba, Asymetry Information dan Pengungkapan Sukarela Terhadap Biaya Modal. Simposium Nasional Akuntansi XV.

Puspita, T. (2011). Analisis Faktor-Faktor yang Mempengaruhi Tingkat Underpricing Saham Pada Saat IPO.

Rastiti, F., \& Stephanus, D. S. (2015). Studi Empiris Tingkat Underpricing Pada Initial Public Offering. Jurnal Akuntansi Multiparadigma (JAMAL), 6, 341-511. https://doi.org/10.18202/jamal.2015.12.6 $\underline{039}$

Sembiring, E. F., Rahmawati, G., \& Kusumawati, F. W. (2018). Analisis Faktor Yang Mempengaruhi Underpricing Pada Perusahaan Yang Terdaftar di Bursa Efek Indonesia Tahun 2010-2016. Jurnal Inspirasi Bisnis Dan Manajemen, 2(2), 167-176. https://doi.org/10.33603/jibm.v2i2.1721

Setyantoto. (2017). Pengaruh Reputasi Underwriter, Reputasi Auditor, Firm Size, Financial Leverage, dan Umur Perusahaan Terhadap Tingkat Underpricing Pada Saat Penawaran Saham Perdana IPO di BEI (Periode 2011-2012).

Setyowati, T. K., \& Suciningtyas, S. A. (2018). Analisis Tingkat Undepricing Saham pada Perusahaan yang Melakukan Penawaran Saham Perdana (IPO) di BEI Periode 2012-2016. EKOBIS, 19(1), 8998.

Sujarweni, V. W. (2017). Analisi Laporan Keuangan. Yogyakarta: Pustaka Baru Press.

Sundarasen, S. D. D. (2019). Institutional Characteristics, Signaling Variables and IPO Initial Returns. PSU Research Review, 3(1), 29-49. https://doi.org/10.1108/PRR-10-2016- $\underline{0003}$

Syukur, M., Fathoni, A., \& Gagah, E. (2016). The Influence of Financial and Non Financial Information on Return Initials in Companies That Conduct IPO in Indonesia Stock Exchange. 1-16.

Wardiyah, M. L. (2017). Analisis Laporan Keuangan. Bandung: CV Pustaka Setia.

Wasiuzzaman, S., Yong, F. L. K., Sundarasen, S. D. D., \& Othman, N. S. (2018). Impact of Disclosure of Risk Factors on The Initial Returns of Initial Public Offerings (IPOs). Accounting Research Journal, 31(1), 46-62. https://doi.org/10.1108/ARJ-09-2016$\underline{0122}$

Widoatmodjo, S. (2015). No Title (R. L. Toruan, Ed.). Jakarta: PT Elex Media Komputindo.

Widoatmodjo, S. (2015b). Pengetahuan Pasar Modal : Untuk Konteks Indonesia (R. L. Toruan, Ed.). Jakarta: PT Elex Media Komputindo.

Wiguna, I. G. N. H., \& Yadnyana, K. (2015). Analisis Faktor-Faktor yang Mempengaruhi Initial Return Pada Penawaran Saham Perdana. E-Journal Ekonomi Dan Bisnis Universitas Udayana, 12, 921-946.

Xu, S., Gong, G., \& Gong, X. (2017). Accruals Quality, Underwriter Reputation, and Corporate Bond Underpricing: Evidence from China. China Journal of Accounting Research, 10(4), 317-339. https://doi.org/10.1016/j.cjar.2017.04.001

Yovita, M., \& Amrania, G. K. P. (2018). The Influence of Intellectual Capital to Market Value with Return on Assets as Intervening Variable. Journal of Accounting Auditing and Business, 1(2), 9-16.

https://doi.org/https://doi.org/10.24198/ja ab.v1i2.18267 